\title{
Klasik Türk Şiirinde Terkiplerdeki Somutlaştırma ve Duygu Aktarımı*
}

\author{
Handan Belli ${ }^{* *}$ \\ Cafer Mum ${ }^{* * *}$
}

$0 \ddot{z}$

Edebî dilde somut ve soyut olanın anlatımında benzetmelere başvurulur. Soyut olanın anlatımında yapılan benzetmeler aynı zamanda birer somutlaştırmadır. Şiirde somutlaştırmaların benzetme yoluyla ve daha çok terkip/tamlama gibi yapılar kullanılarak oluşturulduğu görülmüştür. Klasik Türk şiirindeki terkiplerde somutlaştırma, şairin beyitte oluşturmak istediği hayal ile doğrudan ilgili olup, şiirin kilit taşı görevindedir. Bu çalışmada, klasik Türk şiirinde hemen hemen her şairde rastlanan terkiplerle yapılmış somutlaştırmalar ele alınmıştır. Nâilî ve Neşâtî gibi Sebk-i Hindî şairlerinin yanı sıra Fuzûlî ve Bâkî gibi klasik üslubu benimseyen şairlerden de örnekler seçilerek farklı üsluba sahip şairlerde terkiplerle yapılan somutlaştırma ve duygu aktarımları görülmek istenmiştir. Terkipler aracılığıyla somutlaştırmaların yanında soyut olan duyguların aktarımı da etkili bir şekilde yapılmaktadır. Çalışmanın sonucunda sanatsal dil kullanımlarının gerçekleştiği terkiplerde somutlaştırma ve duygu aktarımı yapılırken şair muhayyilesinin şiire nasıl yansıdığı görülmüştür.

\section{Anahtar Kelimeler}

Klasik Türk şiiri, terkip, soyut, somutlaşıııma, duygu aktarımı.

\footnotetext{
Bu makale Handan Belli'nin Klasik Türk Şiirinde Terkiplerin Edebî Yönü (Fuzûlî, Bâkî, Nâilî ve Neşâtî Örnĕgi) başlıklı doktora tezinden üretilmiştir.

Geliş Tarihi: 06 Mayıs 2017 - Kabul Tarihi: 19 Eylül 2017

Bu makaleyi şu şekilde kaynak gösterebilirsiniz:

Belli, Handan, ve Cafer Mum. "Klasik Türk Şiirinde Terkiplerdeki Somutlaştırma ve Duygu Aktarımı." bilig, no. 97, 2021, ss. 79-108.

** Dr. Öğr. Üyesi, İnönü Üniversitesi, Fen Edebiyat Fakültesi, Türk Dili ve Edebiyatı Bölümü - Malatya/ Türkiye ORCID ID: 0000-0002-7732-7912

handan.belli@inonu.edu.tr

*** Prof. Dr., İnönü Üniversitesi, Fen Edebiyat Fakültesi, Türk Dili ve Edebiyatı Bölümü - Malatya/ Türkiye ORCID ID: 0000-0003-0042-5159 cafer.mum@inonu.edu.tr
} 


\section{Giriş}

Dil ile ifade edilen her duygu ve düşüncenin yapı taşı kelimelerdir. Kelimeler, zaman zaman tek başlarına, zaman zaman bir kelime grubu oluşturarak duygu ve düşünceleri ifade etmede kullanılır. Kelime gruplarından olan terkipler, edebî metinlerde hem dilsel ifadenin bir zorunluluğu hem de edebî dilin önemli bir unsuru olarak yer alırlar. Dilde terkip, "Birleşim, birleştirme, bir araya getirme, tamlama, bileşim” (Türkçe Sözlük 2331) anlamında olup, kısaca birkaç şeyin beraber olmasına veya birkaç şeyin birbirine karıştırılmasına verilen genel bir isimdir. Köken olarak Arapça olan "terkip" sözcüğü kelime birleşimleri yanında ilaç birleşimleri için de kullanılır (Çörtü 13). Osmanlı Türkçesinde çoğunlukla tamlamalar için kullanılan terkip terimi Arapça ve Farsça bir gramer terimi olarak daha geniş bir kullanıma sahiptir.

Osmanlı Türkçesine ait gramer terimlerine bakıldığında tamlamaların "terkip” (Korkmaz 145, Türkay 90, Karahan ve Ergönenç 379, Karahan ve Gürsoy 314), birleşik kelimelerin "elfâz-1 menhûta" (Karahan ve Gürsoy 305), birleşik isimlerin "mürekkep isim” (Türkay 83, Karahan ve Ergönenç 373), birleşik sıfatların ise "mürekkep sıfat" (Karahan ve Ergönenç 373) olarak isimlendirildiği görülmektedir. Osmanlı Türkçesinde terkipler, Türkçedeki karşılığıyla tamlamalar, "Bir ismin anlamının tam olarak belirlenebilmesi için, o ismin, tamlayan görevindeki bir isim veya isim soyundan sıfat, zamir gibi başka bir kelime ile tamamlanması; bir tamlayanla bir tamlananın oluşturduğu kelime grup"larıdır (Korkmaz 145).

Klasik Türk şiirinde kullanılan terkiplerin bir kısmı günlük dilde de kullanılırken bir kısmı yalnızca edebî dile özgü olup, bu dile aşina olmayan kişilerce anlaşılması güç yapılardır. Şiirlerde yer alan kimi terkipleri anlamlandırmada zorlanılmasının sebebi de bu terkiplerin sanatsal bir işlevi yerine getirmek amaçlı kurulmuş dil birlikleri olmasıdır. Günlük konuşma dilinde sanatsal dil kullanımlarına rastlansa da sanatsal dil kullanımları, edebî dilin ağırlıkta kullanıldığı eserlerde yoğun olarak yer alır.

\section{Terkiplerle Somutlaştırma}

Dilde soyut kavramlar betimlenmek, tasvir edilmek istendiğinde soyut olan somut olana benzetilerek somutlaştırılmaktadır. "Somut duruma getirme" (Türkşe Sözlük 2137) olarak adlandırılan somutlaştırmalar, "Şairin muhay- 
yile ve imgelem gücünün bir çeşit dişa vurumudur” (Demirel 42). Dilde somutlaştırmalar, aynı zamanda bir tür aktarma olup deyim aktarmalarının bir kısmına da somutlaştırma adı verilmektedir. Deyim aktarmalarında genel olarak soyut kavramların daha canlı ve somut bir biçimde ifade edildiği görülmektedir (Aksan 138, Yıldırım 212). Terkiplerde somutlaştırma, klasik Türk şairinin sık kullandığı ve özellikle soyut duygularının aktarımına imkân sağlayan bir ifade tarzıdır.

Şiirde soyut kavramların somut unsurlarla ilişkilendirilerek ortaya konulması, Türk şiiri için pek de yeni bir uygulama değildir. Divan şiirinin başlangıcından bu yana şairlerin bu tür bir yaklaşım içinde oldukları bilinen bir gerçektir. Yunus Emre Divanı'ndan itibaren oluşturulan divanların hemen hepsinde soyut kavramların somut unsurlarla birlikte/bir tamlama içinde verildiği görülmektedir. (Demirel 42)

Doğan Aksan, somutlaştırma yoluyla oluşan kelime gruplarının bir kısmını “alışılmamış bağdaştırma”lar grubuna dâhil etmektedir. Ancak somutlaştırma yoluyla yapılmış halkın sıkça kullandığı kelime gruplarının hepsi için alışılmamış bağdaştırma isimlendirmesinin uygun olmadığı düşünülmektedir. Örneğin; "sıcak bakış", "tatlı gülümseme" vb. kullanımlar somutlaştırma yoluyla oluşturulmuştur. Ancak bu terkiplerde somutlaştırma olmasına karşın alışılmamış bir kullanım yoktur, halk tarafından bu terkipler sıklıkla kullanılmakta ve bu kelime grupları ile ne kastedildiği çoğunluk tarafından bilinmektedir. Bu sebeple dilde kullanılan somutlaştırma yoluyla yapılan bütün terkiplerin "alışılmamış bağdaştırma" olarak adlandırılması kapsayıcı bir tanımlama olmamaktadır. Aksan, bazı somutlaştırmalara, zamanla çok kullanılır duruma gelen alışılmamış bağdaştırmalar adını vermektedir (164).

Edebî metinlerde somutlaştırmalar ile alışılmamış bağdaştırmalar oluşturulurken aynı zamanda edebî tasvir yapıldığı görülmektedir. Edebî tasvir, bir şeyi göz önünde canlandıracak şekilde anlatma, dil ile tarif olarak bilinmektedir (Tekin 348). Sanatçı, edebî tasvir ile gerçekte olmayan, yalnızca sanatçının hayalinde yer alan durumları da tasvir etme imkânı bulur. Bu tasvirlerde soyut kavramın somut olana benzetilmesi ve bu somutlaştırmanın da bir terkip/tamlama içerisinde yapılmasıyla somutlaştırma terkipleri oluşturulmaktadır. Klasik Türk şiirinde dikkat çeken somutlaştırma terkipleri, bazı örnekleri alışılmamış bağdaştırma olarak adlandırılan bu yapılar çoğunlukla itibari terkiplerden oluşmaktadır. Somutlaştırma yapılan terkip- 
ler incelendiğinde bu terkiplerin hayalî sahiplikleri, özgülükleri ifade ettiği görülmektedir. Farsçada teşbih ve istiare yoluyla hayalî sahiplikleri anlatan terkipler "izâfet-i itibâriyye" olarak adlandırılır. Nazif Şahinoğlu, bazı dilcilerin "tahsisiyye, itibâriyye diye bir ayrıma yer vermediğini, tahsisiyyeyi mülkiyye, itibâriyyeyi de istiâriyye içinde incelediğini” belirtir (93). Ancak Şahinoğlu, bu şekildeki bir kullanımın mülkiyye terkipleri ile tahsisiyye terkipleri arasında ve itibarî terkipler ile istiare terkipleri arasındaki anlam farkının gözden kaçmasına sebep olacağının alıını çizer. İki terkip türü arasındaki anlam farkının gözden kaçmaması için itibarî terkipler, benzetme ve istiare terkiplerinden ayrı bir başlık altında incelenmesi gerekmektedir. Bazı benzetme ve istiare terkiplerinin de aynı zamanda birer itibarî terkip olduğu da dikkate alınmalıdır.

İtibarî terkiplerin Sebk-i Hindî etkisinde şiir yazan şairlerde sıklıkla kullanıldığg görülmektedir:

Halepli Edîb Divanı'nda biri soyut diğeriyse somut bir kavramı ifade eden sözcükler arasında tamlama yaparak soyutu somutlaştırma örnekleri de önemli bir yekûn tutmaktadır. Farsça izafet çeşitlerinden "izâfet-i itibârî" grubuna giren bu tür tamlamalar da Sebk-i Hindî özelliği olarak kabul edilmektedir. (Mum 174)

Sebk-i Hindî şairlerinin düşünce ve hayalde incelikten ve detayları öne ç1karmaktan hoşlanmaları somutlaştırma terkiplerini daha sık kullanmalarında etkili olmuştur. Örneğin Nâilî, aşağıdaki beytinde kullanmış olduğu "nigeh-i çeşm-i emel" ve "gûşe-i ebrû-yı taleb" terkiplerinde emel ve istek gibi soyut olan iki kavramın detaylarını öne çıkararak onları somutlaştırır:

Neylesin bü'l-heves-i 'aşk olunca derkâr

Nigeh-i çeșm-i emel gûșe-i ebrû-yı taleb (Nâilî G 12/3) ${ }^{1}$

"Emel gözünün bakışı ve istek kaşının köşesi aşk heveslileri devrede olunca ne yapsin?"

Şiirde soyut bir kavramın somut bir varlığa benzetilmesiyle oluşan itibarî terkipler sanat bakımından dikkat çeker. Bu terkiplerde soyut somuta benzetilirken iki kelime arasında tahkikî veya tahayyülî bir ilgi oluşturulmaktadır. Fuzûlî Divanindan alınan aşağıdaki beyitte "mürg-i 'akıl" (akıl kuşu) terkibinde aklın bir kuşa benzetilmesi oldukça dikkat çekicidir ve gerçeklik- 
ten uzak, tamamen hayale bağlı bir benzetmedir. Akıl ve kuş kavramlarının sahip olduğu ortak gösterilenler bu terkibin kurulmasında etkili olur. Aklın, pratik ve hızlı hareket etmesi, aynı şekilde kuşun da hızlı hareket etmesi gösterilenlerine dayanarak akıl ile kuş arasında bir benzerlik kurulduğu görülür. $\mathrm{Bu}$ terkibin yer aldığı beyitte, Mecnun'un çöllere düştükten sonra, aklını yitirmesi ve kuşların başının üstünde yuva yapması olayına telmih yapılır ve Mecnun'un kuşa benzetilen aklının çocuklar tarafından korkutulması ile aklını yitirdiği ifade edilir:

Başdan mürg-i 'akıl uçmaz idi başından

Tifllar üstine taş atmasalar Mecnûnuñ (Bâkî G 283/4)

"Çocuklar Mecnun'un üstüne taş atmasalardı, en önce akıl kuşu başından uçmazdı."

Şairler, soyut olanı veya ifade etmede zorlandıkları duygularını somutlaştırma terkipleri aracılığıyla etkili bir şekilde anlatabilmektedir. Çoğu şairin çöl, vadi gibi coğrafi şekillere fazla yer vermesi, onların yaşadıkları dış dünyayı değil, kendi iç dünyalarını coğrafi şekiller aracılığıyla tasvir ettiklerini gösterir. Aşağıdaki beyitte Fuzûlî, yaşadığı içsel yolculuğun etkisiyle "deşt-i hayret" terkibini kurmuştur. Tasavvufi bir terim olan hayret, "kalbe gelen bir tecellî (vârid) sebebiyle sâlikin düşünemez ve muhakeme edemez hâle gelmesi" dir (Uludağ 231). Bu içsel durumun çöl ile somutlaştırılması, Fuzûlî̉nin hayret hâlini nasıl algıladığını ve yaşadığını gösterir niteliktedir:

Pây-bend-i lutf olup bir yerde sâkin bolmadum

Deșt-i hayretde tereddüdden yorılmış göñlümi (Fuzûlî G 281/5)

"Hayret çölünde oraya buraya gidip gelmekten yorulmuş gönlümü, lütfun ayak bağı ile bağlanmış olarak bir yerde sakin dururken bulmadım.”

Bâkî ise bir beytinde, "arsa-i medh ü senâ" terkibiyle övgülerini meydana benzeterek övgüsünün ne denli fazla olduğunu vurgulamaktadır. İkinci mısrada altı çizili olan terkiple de düşünce, hızlı hareket etmesi yönüyle bir ulağa benzetilerek somutlaştırılmıştır. İkinci mısrada, bir ulağın bin yıl gitmesi hâlinde meydanın sonuna ulaşamayacağı söylenerek övgü meydanının genişliği tekrar vurgulanmıştır. Düşüncenin hızlı hareket etmesi soyut olup, ulağın hızlı hareket etmesi somuttur. Ulağın bu somut özelliği benzetme yoluyla düşünceye aktarılmıştır: 
'Arsa-i medh ü senânuñ bulımaz pâyânın

Peyk-i endîșe eger biń y1l olursa pûyân (Bâkî K 2/35)

"Düşünce ulağı, bin yıl koşsa yine de senin övgü meydanının sonunu bulamaz."

Neşâtî de Bâkînin beytindeki somutlaştırmaya benzer bir somutlaştırma yapmıştır. Bâkî tarafından bir haberciye benzetilen düşünce, Neşâtîde ise yüksekten uçan bir kuşa benzetilerek somutlaştırılmıştır:

Hem-ser-i küngüre-i 'arş-1 berîn kim çıkamaz

Murg-1 endîșe eger eylese bin yıl pervâz (Neşâtî K 14/15)

"Düşünce kuşu bin yıl kanat çırpsa, yüksek arş kubbesinin seviyesine çıkamaz."

Somutlaştırmalar, soyut olan kavramı şairin nasıl algıladığıyla doğrudan ilgilidir. Bu sebeple terkiplerdeki somutlaştırmalar da şairlerin algıları, ruhsal durumları ve deneyimleri hakkında bilgiler vermektedir.

Algılamanın ve bunun ürünü olan algının hammaddesi duyumlardır. Duyumların hemen hepsi bir algıyla sonlanır. Algılama süreci nesnelerin ya da olayların insanın bilinç alanına yansıması olarak görülebilir. Bu süreç insanın öğrenmesiyle, eski yaşantıları ve deneyimleriyle, beklentileriyle, ruhsal durumuyla, toplumsal ve kültürel etkenlerle yakından ilişkilidir. (Doğan 55)

Aşağıya alıntılanan beyitte gam bir bağa benzetilerek somutlaştırılmıştır. Gönül de bu bağın bülbülü olarak ifade edildiğinde somutlaştırma daha da detaylandırılmış olur. Şairin aşağıdaki altı çizili terkipte gam gibi acı veren bir duyguyu da bağa benzetmesi gamı kendisine acı veren bir duygu olarak değil, içinde olmaktan mutluluk duyduğu bir yer olarak algıladığını göstermektedir:

Gönül sen andelîb-i bâğ-1 gamsın durma feryâd et

Ki bûy-1 dâğ-1 hayret nefha-pîrâ-yı dimâğundır (Nâilî G 75/2)

"Gönül, sen gam bağının bülbülüsün, durmadan feryat et. Çünkü hayret yarasının kokusu, dimağına koku vermektedir.”

Klasik Türk şairi gerçekte var olmayan bir durumu, zihninde canlandırıp bu hayali somutlaştırma terkipleriyle şiire aktarabilmektedir. Aşağıdaki bey- 
tin birinci mısrasında yer alan "sümûm-1 bâdiye-i ye's" (ümitsizlik çölünün zehri) ve "şemîm-i tarab" (sevinç kokusu) somutlaştırma terkipleri şairin hayalinde tasavvur ettiği durumlardır. Benzer şekilde ikinci mısrada yer alan "riyâz-1 baht" (baht bahçesi) ile "nesîm-i tarab" (sevinç rüzgârı) somutlaştırma terkipleri aynı muhayyilenin birer parçasıdır. Birinci mısrada ümitsizlik bir çöl gibi tasvir edilmiş ve bundan dolayı çölün genişlik, sonsuzluk özellikleri ümitsizliğe aktarılmıştır. "Sümûm-1 bâdiye-i ye's" terkibinde ümitsizliğin bir çöle benzetilmesi ile bu yerin kişi üzerindeki olumsuz etkisi de zehir ile somutlaştırılmaktadır. Ümitsizlik, çöl gibi durağan ve geniş bir mekân ve zehir gibi öldürücü etkisi olan bir nesneyle tasvir edilmiştir. İkinci mısradaki terkipte ise baht bir bahçeye benzetilmiş ve bahçenin tüm özellikleri bahta aktarılmıştır. Böyle bir bahçede esen rüzgâr da sevinç rüzgârı olarak tasvir edilmiştir:

Sümûm-1 bâdiye-i ye's olur șemîm-i tarab

Riyâz-1 bahtıma olsa vezân nesîm-i tarab (Nâilî G 14/1)

"Baht bahçeme sevinç rüzgârı esecek olsa, sevinç kokusu ümitsizlik çölünün zehri olur."

Yukarıdaki somutlaştırma örneklerinde de görüldüğü gibi terkiplerle somutlaştırmalar görme, tatma, dokunma, koklama ve işitme olmak üzere beş duyu kullanılarak yapılmaktadır. Klasik Türk şiirinde her şairin divanında da rastlanabilen bu somutlaştırmaların duyular yardımıyla nasıl yapıldığı Fuzûlî, Bâkî, Nâilî ve Neşâtî̀nin divanlarından alınan örnekler üzerinden aşağıdaki başlıklar altında incelenecektir.

Görme Duyusuyla Somutlaştırma

Klasik Türk şiirinde görme duyusuyla yapılan somutlaştırmalarda göz ile algılanamayan bazı soyut kavramların, şair tarafından görülebilmesi mümkün olan varlıklar gibi tasvir edilerek somutlaştırıldığı görülmektedir. Örneğin sevinç gibi soyut bir duygunun renginin görülmesi veya gam gibi soyut bir duygunun şekil olarak bir nesneye benzetilmesi, şairlerin soyut kavramları da görme duyusuyla tasvir ettiğini göstermektedir. Görme duyusu ile somutlaştırmalarda soyut kavramlar çoğunlukla ışık, renk ve şekil yönüyle tasvir edilir. Bu sebeple göz ile somutlaştırmalarda soyut olan kavram bir ışı̆̆a, renge veya şekle sahipmiş gibi resmedilir. 
Şiirde edebî tasvir amaçlı kurulan terkiplerin çoğunlukla göze hitap eden tasvirler olduğu görülmektedir. Örneğin aşağıdaki beyitte "vâdî-i 'aşk" terkibiyle aşkın vadi olarak tasvir edildiği ve bu zemin üzerinde gönlün istek eteğini tuttuğu hayali çizilmiştir. İkinci mısrada "gûşe-i dâmen-i nev-şâhid-i dil-cûy-1 taleb" zincirleme terkibi ile isteğin daha ayrıntılı tasvir edildiği görülmektedir. İstek, gönlü çeken bir sevgiliye benzetilmiştir. Kişinin isteklerinin taze bir sevgiliye benzetilmesi oldukça orijinal bir kullanımdır. Bu terkipte dikkat çeken diğer bir nokta ise isteğin ete kemiğe bürünmüş bir sevgili olması ve gönlün onun eteğinin ucunu tuttuğu hayalidir:

Vâdî-i 'aşkda girmez mi daha dest-i dile

Gûsse-i dâmen-i nev-şâhid-i dil-cûy-1 taleb (Nâilî G 12/4)

"Aşk vadisinde, isteğin gönül çeken taze sevgilisinin eteğinin ucu gönül eline girmez mi?"

Genel olarak olumlu duygular, 1şılkla bağdaştırılmakta ve ışık kişiye iyiliği, yaşamı çağrıştırmaktadır. Işığın karşısında ise karanlık yer alır ve karanlık, yaşamın tersi olan ölüm ve gazabı temsil etmektedir (Hacızade 79). Aşağıdaki beyitte irfan gibi soyut bir kavramın parlak bir nesne gibi tasvir edilerek somutlaştırıldığı görülmektedir. Beyitte, irfan nurları kalbe dolduğunda oraya yanlış düşüncelerin giremeyeceği ifade edilerek irfanın bulunduğu yeri aydınlattığı vurgulanmıştır:

Dil-i pür-nûruna kılmaz güzâr efkâr-i nâ-sầib

Kim ol kandîl memlûdur leb-â-leb nûr-1 irfândan (Fuzûlî K 38/20)

"O kandil, ağzına kadar irfan nuruyla dolu olduğundan nur dolu gönlüne yanlış düşünceler girmez.”

Bâkînnin bir gazelinde kullanmış olduğu "çerâğ-1 lutf" terkibi de soyut kavramların ışıklı bir varlık gibi tasvir edilerek somutlaştırılmasına örnektir. Bu terkipte hoşluk, iyilik anlamına gelen "lutf” un ışık veren bir nesne gibi tasvir edilmesi ve bağ gibi bir mekânın lütfun ışığıyla aydınlanması şairin muhayyilesinde oluşturduğu hayali aktarmasının bir sonucudur:

Nûr-bahş olsa eger bâğa çerâğ-1 lutfuñ

Şem'-vâr eyleye etrâfı münevver sünbül (Bâkî K 24/26)

"Eğer lütfunun kandili bağa nur saçarsa, sümbül de mum gibi etrafı ışıklandırır." 


\section{Tatma Duyusuyla Somutlaştırma}

Klasik Türk şiirinde bazı soyut kavramlar tat duyusuyla somutlaştırılmaktadır. Bu somutlaştırmalarda soyut kavram, verilmek istenen duyguya göre tatlı, acı, ekşi ve tuzlu tatlara benzetilerek somutlaştırılır. Bu şiirlerde tatma duyusu ile somutlaştırma yapılırken en çok kullanılan tatların başında şarap gelmektedir. Başka içecekte olmayan sarhoş etme, kendinden geçirme özelliklerinden dolayı şarabın bazı soyut kavramları somutlaştırmada kullanıldığı tahmin edilmektedir. Özellikle aşkın, insan üzerindeki etkilerini somut olarak ifade ederken şarabın somutlaştırma nesnesi olarak tercih edildiği görülür. Bu amaçla kurulan "bâde-i 'aşk" (Bâkî G 421/4), "şarâb-1 'aşk u mahabbet”" (Bâkî G 46/3), "mey-i 'işk”" (Fuzûlî G 131/5, Neşâtî G 53/4), "mest-i mey-i 'işk" (Fuzûlî G 161/6) vb. terkipler aracıl1ğıla aşk gibi soyut bir kavram, şaraba benzetilerek anlatılmakta, şarabın insanı kendinden geçirme ve sarhoş etme özellikleri aşka aktarılmakta ve şarabın içildikten sonra verdiği etkilerin aşk ile benzer olduğu vurgulanmaktadır. Aynı şekilde şarap içildikten sonra ortaya çıkan baş ağrısı gibi kötü etkiler aşkın kişiye verdiği acı duygusuyla benzerlik oluşturmaktadır. Özellikle “'mey-i 'aşk' gibi benzetmeye dayanan tamlamalarda içki kendi hakiki/temel anlamını muhafaza etmektedir" (Saraç 141). Burada kastedilen hakiki/temel anlam şarabın sarhoşluk verme özelliğidir. Şarap ile aşkın bu özelliklerinden hareketle mutasavvıflar "sekr" ile "muhabbet" lafızları arasında bir bağ kurmuşlardır:

Sözlükte sekr, sarhoşluk anlamına gelmektedir. Fakat mutasavvıflar bu kelimeyi, tam anlamıyla bâtınî bir boyut taşıyan başka bir anlamda kullanmaktaydılar. Bu batınî kavram tasavvuftaki bir başka temel kavrama, 'muhabbet' kavramına dayanmaktadır. Dolayısıyla tasavvuftaki 'sekr' istılahı ve bu istılah yoluyla kullanılan 'şarap' ya da 'hamr' kelimesi vs. başından beri muhabbet kavramından yararlanılarak tanımlanmaktaydı. (Pürcevâdî 304-305)

Şarabın kendisinden değil kişi üzerindeki etkilerinden yararlanan mutasavvıf, somutlaştırmaları birer varsayım ve benzetme üzerine temellendirmiştir. Örneğin aşağıdaki beyitte ayrılık meclisinde aşkın ve muhabbetin çok olduğu anlatılmaktadır. Ayrılık meclisinde aşk ve muhabbetin çoğaldığı, şarabın testi testi olması ile somutlaştırılmış, böylece bu soyut kavramlardaki artma somut bir şekilde ifade edilmiştir: 
Yanınca bâde-güsârân-ı bezm-i hicrânın

Şarâb-1 'așk u mahabbet sebû sebû biledir (Nâilî G 46/3)

"Ayrılık meclisinin şarap içenleri yanında aşk ve muhabbet şarabı testi testidir."

Klasik Türk şiirinde şarap ile yapılan somutlaştırma terkiplerinin bazen istiareye döndüğü görülmektedir. Şiirde şarap istiarelerinin, sıklıkla "şarâb-1 'aşk” somutlaştırma terkibinin bir ögesinin söylenmemesiyle oluştuğu bilinmektedir. Bu sebeple birçok kaynak, şarap istiaresi ile aşkın kastedildiğini ifade eder (Uludağ 485, Pürcevâdî 343, İz 159).

Sonraki dönemlerde de daha önce değindiğimiz gibi, tasavvufi şiirlerde şarap, bâde ve mey, çeşitli şeylerin, bu cümleden olarak da aşkın "müşebbehün bih"i olmaktadır. Fakat teşbih istiareye dönüşünce şarap, bâde ve mey genellikle aşk ya da sevgi anlamına alınmıştır. (Pürcevâdî 345)

İlahî veya beşerî anlamda âşık olan kişide meydana gelen değişiklikler, içki içen kişide meydana gelen değişikliklere benzetilir. Beyitte sarhoş olan kişi sarhoşluğunu nasıl gizleyemezse âşığın da bu durumunu gizleyemediği vurgulanmıştır:

Mey-i 'ișkuñla ser-mest olduğum ilden nihân kalmaz

Muhâl-i akldur kim saklaya râz-1 nihân sarhoş (Fuzûlî G 131/5)

"Aşk şarabınla sarhoş olduğum başkalarından gizli kalmaz. Sarhoşun sırını saklaması akıl dışıdır."

Dokunma Duyusuyla Somutlaştırma

Eşyanın sertlik, yumuşaklık, sıcaklık vb. özellikleri dokunma duyusu ile algılanabilmektedir. Klasik Türk şiirinde birtakım soyut kavramların sertlik, yumuşaklık vb. özellikleri vurgulanarak somutlaştırıldığı görülür. Soyut kavramlara dokunmak mümkün değilken bazı terkiplerde onların dokunma duyusuyla algılanıyor gibi tasvir edildiği görülmektedir. Dokunma duyusu ile yapılan somutlaştırmalarda, soyut bir kavrama dokunmadan o kavramın sıcak, sert veya yumuşak bir nesneye benzetilerek somutlaştırılmasıyla bu kavram hakkında daha ayrıntılı bilgi verilebilmektedir. Fuzûlînnin şiirlerinde "seng-i melâmet" (G 10/6, G 16/2, G 91/5, G 166/6, G 238/1) terkibini sık kullandığı görülür. Melâmetin sözlük anlamı ayıplama, kınama olup, bu 
soyut kavram dolaylı olarak taş ve taşlamayı akla getirmiştir. Tasavvufta melamet, "halkı kendisinden nefret ettirmek için şeriatte zararı olmayan şeyleri yapmayı gerektirir" (MTTS 647). Melamet yoluna giren kişinin halktan kopması, onlara bağlanmaması için kınanması gerekmektedir. Bu sebeple melamet için "selameti terk etmek" (Uludağ 356) gerekmektedir. Melamet, selameti terk edip, zor olanı seçmektir. Bu nedenle şair, bu soyut kavramı taşa benzeterek ve kınamayı akla getirecek şekilde kullanarak somutlaştırmıştır:

Yüceldüñ kabrüm ey bî-derdler seng-i melâmetden

Ki ma'lûm ola derd ehline kabrüm ol alâmetden (Fuzûlî G 238/1)

"Ey dertsizler, melamet taşından kabrimi yükseltin. Dert ehline kabrim o izlerden belli olsun."

Koklama Duyusuyla Somutlaştırma

Terkipler aracilğ̆ıla soyut bir kavramı görme, dokunma, tatma yoluyla somutlaştıran şairler, bazı soyut kavramları da bir kokuya sahipmiş gibi tasvir ederek somutlaştırma yoluna gitmişlerdir. Aşağıdaki beyitte safa gibi soyut bir kavramın kokusunun olduğu belirtilir. Böyle soyut bir kokuyu da ancak gönül burnu koklayabilmekte, dolayısıyla safa gönül tarafından koklanabilen bir nesne gibi somutlaştırılmaktadır:

Yok bûy-1 safâ meşâm-1 dilde

Âşüfte-dimâğ-1 derd-i 'işkuz (Neşâtî G 52/4)

"Aşk derdinin aklı perişanıyız. Gönül burnunda safa kokusu yok."

Aşağıdaki beyitte de "bûy-1 hulk" terkibiyle şair, somut olarak koklanan veya kokan bir kavram olmadığı hâlde yaratılışın bir kokusunun olduğunu belirtmiştir. Hayalde var kabul edilen bu koku, yine hayalen var kabul edilen lâlenin burnuna ulaşmaktadır. "Bûy-1 hulk" terkibi ile aynı zamanda her kişinin kendisine has bir yaratılışa sahip olma özelliği de vurgulanır:

Bînî-i gonce-i lâle ola fevvâre-i hûn

Bûy-1 hulkıyla sabâ eylese gülzâre 'ubûr (Neşâtî K 16/20)

"Saba rüzgârı yaratılışının kokusuyla gül bahçesine esse, lâle goncasının burnu kan fiskiyesi olur." 


\section{İşitme Duyusuyla Somutlaştırma}

Şiirde soyut kavramların bir kısmı, işitme duyusu ile algılanabilir şekilde somutlaştırılabilmektedir. Ölümün sesinin duyulması, acının çı̆̆lığının olması işitme duyusuyla yapılan somutlaştırmalara örnektir. Fuzûlî, aşağıdaki beytinde, ölüm gibi sessiz ve acılı bir hadiseyi "bang-i rihlet" terkibi ile işitme duyusuyla algılanır şekilde somutlaştırır. Ölüm, etkileri görülen ama kendisi görülmeyen soyut bir kavramdır. "Bang-i rihlet" terkibinde "rihlet" in göç anlamına gelmesi ve göç yapılacağı zaman davul çalınması adeti dolayısıyla bu kelime iki bağlamda da düşünülmelidir. Bu bağlamdan yola çıkılarak "bang-i rihlet" terkibi "göç davulunun sesi" olarak çevrilebilmektedir. Ancak bir diğer bağlamında göç ile ölüm kastedildiğinden bu terkipte kapalı istiare yapılarak ölüm, göç davuluna benzetilmiş, dolayısıyla ölüm işitme duyusuyla somutlaştırılmışıtır:

Yeter oldı kulağa bang-i rihlet dehr bâğından

Ne durmışsun temâşâ-yı gül-i ruhsâr yetmez mi (Fuzûlî G 283/4)

"Dünya bağından göç davulunun sesi kulağa gelmeye başladı. Ne durmuşsun, yüz gülünün temaşası sana yetmez mi?”

Beyitteki "bang-i rihlet" somutlaştırma terkibini kuran şair, aynı zamanda ölümün ansızın ve sessizce gelme özelliğini kabul etmediğini ve aksine ölümün varlığını her zaman insanlara duyurduğunu belirtmektedir.

Terkiplerde somutlaştırma yapilırken seçilen kelimeler, beyitte kurulmak istenen hayal ile doğrudan ilgilidir. Bu sebeple terkiplerdeki somutlaştırmaların doğru anlaşılması için beyitte kurulan hayale de dikkat edilmelidir.

\section{Terkiplerle Duygu Aktarımı}

Aktarım, bir eşyayı, bir yolcuyu veya bir toprağı devretme, dilde ise bir kelimenin anlamını dolayısıyla tüm gösterilenlerini o kelimeden başka bir kelimeye yükleme, devretme eyleminin genel adıdır. Dilde var olan yapıların tanımlanmasında önemli çalışmaları olan Doğan Aksan, şiir dilinde aktarmaları; deyim aktarmaları ve ad aktarmaları-öteki aktarmalar olmak üzere iki grupta sınıflandırmaktadır. Aksan (126-148), şiir dilinde aktarmalar başlığı altında yer alan deyim aktarmalarını kendi içerisinde dört grupta sınıflandırır: 1. İstiare 2. İnsandan doğaya aktarma (kişileştirme) 3. Somutlaştırma 4. Sinestezi. Aksan, ad aktarmaları-öteki aktarmalar başlığı altında ise mecaz-1 mürsel sanatına yer vermektedir. 
Dilde anlam aktarımlarıyla beraber sanatsal dil kullanımlarıyla duygular da aktarılmaktadır. Dil, "gözlenemeyen iç dünyayı gözlemlenen dış dünya, maddî dünya örneğine göre modelleştirir” (Hacızade 72). Şair, iç dünyanın aktarımını ancak dış dünyada herkes tarafından bilinen nesnelerin kullanımıyla gerçekleştirir. Bu nesnelerin kullanımı ile yapılan duygu aktarımlarında duygu aktarma nesnesi ve duygu aktarma kaynağı iki önemli unsurdur. Duygu aktarımlarında aktarma nesnesi ile aktarma kaynağı arasında benzerliğe dayalı bir ilişki vardır (Hacızade 72). Nesne ve aktarma kaynağı arasında benzerlik olmadığı takdirde duygu aktarımlarında gösteren ile gösterilen arasında kesinti yaşanması söz konusudur. Kelimelerin duygu değerleri o kelimenin kişi üzerinde bırakmış olduğu etkiyle doğrudan ilgilidir. "XIX. yüzyılın sonlarında K. O. Erdmann bu türden göstergelerin duygu yönünü duygu değeri ya da ruhsal durum değeri (Alm. Gefühlswert oder Stimmungsgehalt) terimiyle adlandırmıştır" (Aksan 100). Kelimelerin duygu değerleri onların "connotation" "yan anlam" ından çok asıl olarak kişide bırakmış olduğu etkileri kapsar.

Şiirin bir amacı, belli bir göstereni hep aynı gösterilene ve göndergeye mahkûm olmaktan kurtararak, dilin olanaklarını zorlamak ve tüm insanlarda az veya çok bulunan ya da bilinen, gözlemlenen duygu, özellik ve yaşantıları yeni bağdaşımlarla yeniden yaratmak ve iletmektir. (Korkut 31)

Kelimelerin kişi üzerinde bırakmış olduğu etkiler kelimenin duygu değeridir. Klasik Türk şiiri terkiplerinde kelimelerin özellikle duygu değerleri dikkate alınarak seçildiği görülmektedir:

Şiir dilinde duygu değeri taşıyan tek tek ögeler kadar, birden çok göstergelerden kurulan alışılmamış bağdaştırmalar da yarattıkları değişik, çeşitli tasarımlarla birlikte okuyan/dinleyene aktardıkları duygu değerleriyle etkili olmakta, güçlü bir anlama eriştirmektedir. (Aksan 101)

Duygu aktarımlarında şairin bilişsel dünyası etkindir. Şair algısına göre çeşitli duygu aktarımları yapabilir. Ölümün acı, sevginin ise tatlı bir tat ile ifade edilmesi şairin algısına dayalı aktarımlardır. Klasik Türk şiirinde kelimelerin duygu değerleri kullanılarak yapılan duygu aktarımlarında en çok renklerden ve şekillerden faydalanıldığı görülmektedir. İnsan duygularının gözlemlenmesiyle hangi rengin hangi duyguya işaret ettiği bilimsel çalışmalarla ortaya konulmuştur. İnsanın öfkelendiğinde yüzünün kızarması, 
üzüldüğ̈nde yüzünün sararması veya korktuğunda yüzünün beyazlaması nedeniyle kırmızı kızgınlık, sarı hüzün, beyaz ise korku duygusunu aktarmaktadır. Bu renklere sahip nesneler kullanılarak da renk ile duygu aktarımı yapılabilmektedir.

İbn Sina'ya (208) göre, '(Asıl anlamından) intikal etmiş istiareli sözün etkisinin çeşitli dereceleri vardır. Mesela, (şairin) gazelde sevgilinin parmağını tasvir ederken, onun kırmızı olduğunun veya özellikle kıpkırmızı olduğunun söylemesindense kırmızılığı anlatmak için 'pembe/ gül rengi' demesi daha etkilidir. Bununla, gülün letafeti hayal edilir ve mutlak olarak onun kırmızı olduğunu söylemenin hayalde canlandıramadığı şey anlaşılır. 'Kırmız’' lafzı, kendisiyle beraber bir övgü ve güzel bulma anlamını taşımaz. 'Koyu kırmızı' denmesi ise bozulmuş bir gülü canlandırmaktan başka işe yaramaz’. (Gemuhluoğlu 138-139)

Şairler belli bir amaç doğrultusunda renkleri kullanarak istedikleri anlam ve duygu aktarımını yapabilme imkânı bulurlar. Bu bağlamda hem olumlu hem olumsuz duyguların belirtisi olduğu için renklerin sevinç, sevgi, öfke, kin, utanç gibi birbirinden farklı duyguların aktarımında kullanıldığı görülmektedir (Hacızade 81). Renk ve şekil anlamına sahip olan kelimelerin duygu değerlerinin dildeki diğer kelimelere göre fazla olması bu kelimelerin terkiplerde sıklıkla kullanılmasında etkili olmuştur.

Klasik Türk şiirinde soyut kavramların fiziksel özelliği ön planda olan taş ve çöl gibi somut varlıklara benzetilmesiyle bu terkipler aracılığıyla anlam ve duygu aktarımı yapılmakta, aynı zamanda kelimelerden tasarruf da sağlanmaktadır. Örneğin, "vâdî-i şerm”, "tîh-i gam” vb. terkiplerde utanma duygusunun uzunluğunun vadi ile gamın büyüklüğü ve yakıcılığının ise çöl ile aktarıldığı görülmektedir:

Fikr ider bu vâdî-i șerme hayâl-i beste-dem

Olsa hamuş 'aceb degül 'acz ile kilk-i ter-zebân (Neşâtî G 91/4)

"Suskun hayal, bu utanma vadisini düşündügünde hazırcevap olan kalem, acz ile sussa şaşılmaz.”

Klasik Türk şiirinde renkler ve şekiller sıklıkla kullanılır. Şairler, renkleri ve şekilleri kullanarak dış dünyada görülen veya görülemeyen kavramların tasvirini yaparken birtakım duyguları etkili bir şekilde aktarabilme imkânı bulur. 
Duyguların, etkili bir şekilde günlük dille anlatılması daha zorken edebî dilde imgeleme ve aktarma yoluyla daha kolaydır. Bu imgeleme ve aktarmalar duygu değerleri yüksek olan kelimeler ile soyut kelimeler arasında kurulan terkiplerle gerçekleşmektedir. Olumlu ve olumsuz duyguların terkiplerle somutlaştırılmasının şiir dilinde oldukça sık kullanıldığı görülmektedir.

\section{Sevgi Duygusunun Aktarımı}

Klasik Türk şiirinde en çok somutlaştırılan olumlu anlamdaki duyguların başında ise sevgi/aşk gelmektedir. Şiirde sevgi duygusu birçok somut varlıkla terkip oluşturularak kullanıldığında sevginin kişi üzerinde bırakmış olduğu etki somut şekliyle aktarılabilmektedir. Örneğin aşağıdaki beyitte aşırı sevgi olan aşk, cevhere benzetilerek somutlaştırılmıştır. Cevherin değerli ve ele geçmesinin zor olmasından hareketle aşkın da değerli ve elde edilmesinin zor olduğu "gevher-i 'aşk" somutlaştırmasıyla aktarılmıştır:

Cân gibi eder gevher-i 'aşkın yine pinhân

Sad pâre de olsa sadef-i sîne-i âşsı (Nâilî G 196/4)

"Âşık sinesinin sedefi yüz parça olsa da aşk cevherini yine can gibi gizler."

Fuzûlî, Bâkî, Nâilî ve Neşâtî̀nin divanlarında sevgi/aşk ile ilgili yapılan ortak somutlaştırmalardan biri de deniz ile yapılmışır. Bu somutlaştırmalarda sevgi/aşk, büyüklüğü ve enginliğiyle denize benzetilmektedir:

Girye-i zâr ile hoş-hâlem ki bahr-i 'işsda

Eşksiz göz bir sadefdür lü'lü-i şehvârsız (Fuzûlî G 117/5)

"Aşk denizinde inlemeli gözyaşıyla hoş bir hâldeyim. (Çünkü) gözyaşı olmayan göz, şahlara layık incisi olmayan bir sedeftir."

Bu beyitte deniz olarak somutlaştırılan aşkta, âşığın gözyaşlarının çok olması normal bir durum olarak belirtilmiş ve aşk denizinde gözyaşı dökmeyen gözün, iri incisi olmayan sedef gibi olacağından makbul sayılmayacağı belirtilmiştir.

Sevinç Duygusunun Aktarımı

Klasik Türk şiirinde sevincin, ışık gibi etrafı aydınlatan somut bir nesne olan muma, gül gibi etrafa koku ve güzellik veren bir nesneye veya bayram gibi 
kişiyi mutlu eden zamanlara benzetilerek somutlaştırıldığı sık görülmektedir. Sevincin ışığa sahip olan varlıklarla somutlaştırılmasında parlaklığın ve 1şığın sahip olduğu olumlu anlamlar etkilidir. Şiirde de çoğunlukla nur olarak yer alan ışık, sevgili ve sevgilinin güzellik unsurlarıyla aynı terkipte yer alır. Aşağıdaki beyitte geçen "nûr-1 sürûr" terkibinde sevinç, ışık saçan ve insanın içini aydınlatan bir varlık gibi tasvir edilerek somutlaştırılmıştır. Beyitte çemen meclisindeki bu sevinç sebebiyle gam ve karanlığın lamba ile aransa dahi bulunamayacağı ifade edilir. Beyitteki bu somutlaştırma ile sevincin olduğu yerde gama ve karanlığa yer olmadığı vurgulanmaktadır:

Şâh-1 gül virdi çemen bezmine bir nûr-1 sürûr

Ki çerağ ile bulunmaz eser-i zulmet ü gam (Fuzûlî K 31/4)

"Gül dalı çemende kurulan meclise bir sevinç ışığı verdiğinden gam ve zulmetin eseri lamba ile aransa bulunmaz."

Bulunduğu ortama verdiği olumlu etkiler göz önüne alınarak sevinç, terkiplerde sıklıkla ışık ile somutlaştırılmıştır:

Ger olsa șem'-i neșât-1 derûnı şu'le-fiken

Olurdı gün gibi rûşen derûn-1 tîre-i gam (Neşâtî K 21/29)

"Eğer iç sevincinin mumu ışık saçacak olsa gam karanlığının içi gün gibi aydınlık olurdu."

Sevinç duygusu diğer bir beyitte ise kilim ile somutlaştırılarak bu duygunun verdiği rahatlık hissi somut şekilde aktarılmıştır:

Gördüm yirüm fezâ-yı bisât-i sürûr iken

Olmış mazîk-i mezbele-i acz ü inkisâr (Fuzûlî K 39/23)

"Yerim, sevinç kiliminin fezası iken, gördüm ki acz ve kırılma mezbelesinin dar yeri olmuş."

Sevinç duygusunun kişiyi iyileştirme özelliği ise sevincin merheme benzetilmesiyle aktarılmıştır:

Biz çâk çâk-i tî̆g-i gamız hergiz olmasın

Zahm-âşinâ-yı cân u ciger merhem-i neșât (Nâilî G 187/4)

"Biz gam kılıcının açtı̆̆ı derin yarayız. Sevinç merhemi hiçbir şekilde can ve ciğer yarası ile tanışmasın.” 


\section{Ümit Duygusunun Aktarımı}

Çeşitli nesnelere benzetilerek somutlaştırma yoluyla aktarılan duygulardan biri de ümittir. Ümit, bir kişide var olduğunda onu olumlu yönde etkileyen duygulardandır. Klasik Türk şiirinde terkiplerle ümit duygusunun okuyucuya aktarılmasında ümidin bu olumlu anlamı ön plana çıkarılmaktadır. Örneğin aşağıdaki beyitte geçen "benefşezâr-1 ümîd" terkibiyle şair ümidi, menekşe tarlasına benzeterek somutlaştırdığında bu çiçeğin renk ve duygu değerinden faydalanmakta ve ümidi olumlu bir duygu olarak aktarmaktadır:

Meger ki sîne-i uşşâkı tâze nev-hatlar

Duhân-1 âh ile eyler benefșezâr-1 ümîd (Nâilî G 30/4)

"Meğerki yüzü yeni tüylenen körpe gençler, âşıkların sinesini âh dumanı ile ümidin menekşe tarlası yapar.”

Öfke, Korku ve Üzüntü Duygusunun Aktarımı

Şairler, sevinç, neşe, ümit vb. olumlu duygularının yanı sıra öfke, korku, üzüntü vb. olumsuz duygularını da somutlaştırarak etkili bir şekilde aktarmaktadır. Öfke ve kızgınlık gibi duyguların Fuzûlî ve Bâkînnin divanlarında somutlaştırılmadığı, ancak Nâilî ve Neşâtîn nin divanlarında terkiplerle somutlaştırılarak daha etkili bir şekilde aktarıldığı görülmektedir. Örneğin aşağıdaki beyitte Nâilî, öfke duygusunu ateşe benzeterek etkili bir şekilde aktarmaktadır. Öfke ile vücut sıcaklı̆̆ının artması ve bunun yanında öfke ile hareket edildiğinde ortaya çıkan eylemlerin yakıcı, üzücü şeylere sebep olması nedeniyle bu duygu ateş ile somutlaştırılmış ve yapılan somutlaştırma ile öfkenin yakıcıllı̆̆ aktarılmıştır:

Husrev-i şîr-i 'adû-sûz ki nâr-1 gazabı

Cây-1 âhû-bereyi pençe-i şîrân etmiş (Nâilî K 9/16)

"O düşmanın canını yakan aslan padişah olduğundan gazap ateşi, ceylan yavrusunun yerini aslanların pençesi etmiş.”

Korku, dış etkenlere bağlı olarak oluşan ve kişiyi her anlamda olumsuz etkileyen duygulardan biridir. Şiirde korkunun insan üzerindeki olumsuz etkileri birtakım somut nesnelere benzetilerek anlatılmıştır. Aşağıdaki beyitte korkunun fazlalığı ve kişiye zarar vermesi yönü sel benzetmesiyle aktarılmıştır: 
Bu râzı derkde kem-mâyedir hıred yâ Rab

Rızâsı cûșiş-i seylâb-1 vehme sedd-i sedîd (Nâilî K 7/54)

"Ya Rab, akıl bu sırrı kavramada kusurludur. Rızası korku selinin coşmasının önünde güçlü bir settir.”

İnsanın yaşadığı bela, sıkıntı ve acı veren olaylar neticesinde yaşamış olduğu duyguların başında üzüntü gelir. Şiirde üzüntü duygusu çoğunlukla yaşanılan bela, sıkıntı, kahır ve gam kavramları ile anlatılmaktadır. Özellikle üzüntüye sebep olan bu soyut kavramlar "âteş" ve "nâr" kelimeleriyle somutlaştırılarak anlatılmaktadır. Nâr-1 hecr (Bâkî G 176/1), nâr-1 kahr (Bâkî K 5/11), nâr-1 mihnet (Bâkî G 236/2), nâr-1 firâk (Bâkî G 422/5), nâr-1 fürkat-i şehd-i leb (Bâkî G 225/3), nâr-1 gam-1 'aşk (Bâkî M8 2/1), nâr-1 gam-1 fürkat (Bâkî G 335/5) terkiplerinde ayrılık, kahır, sıkıntı, gam gibi üzüntüye sebep olan kavramlar dokunma duyusu ile hissedilir şekilde aktarılmıştır. Kahır çeken kişinin yaşadığı üzüntü, klasik Türk şiirinde somut şekilde acı veren, yakan, batan, kişiyi yaralayan nesnelere benzetilerek anlatılmaktadır. Örneğin aşağıdaki beyitte insan vücudu bir tunç madenine benzetilir ve insanın yaşadığı kahır sonucu tunca benzeyen vücudunun eridiği ifade edilmektedir. Kahrın yakıcılığı, dolayısıyla üzüntünün kişiyi bitirebilmesi yönü tunç madeni gibi olan vücudun erimesiyle anlatılmıştır:

Su gibi nâr-1 kahrından erîr bir demde rûyîn-ten

Tokınsa şu'le-i şemşîri nerm eyler Nerîmânı (Bâkî K 5/11)

"Tunç vücutlu, kahır ateşinden bir anda su gibi erir. Kılıcın ışığı dokunsa Nerîman'ı yumuşatır.”

Câm-1 bezm-i rezmüñ içmekde dil-i düşmen kebâb

Def́-i hâr-i kahruñ etmekte hayâl-i hasm hâm (Fuzûlî K 24/20)

"Savaş meclisinin kadehini içmekte düşman gönlü kebap olmuştur. Senin kahır dikenini def etmekte düşman hayali olgunlaşmamıştır.”

Duyguların terkiplerle aktarımına örnek olması amacıyla aşağıdaki tabloda üzüntü duygusunun Fuzûlî, Bâkî, Nâilî ve Neşâtînnin divanlarında hangi kelimeler kullanılarak somutlaştırıldığı karşılaştırmalı olarak gösterilmiştir: 


\section{Tablo 1}

Öfke, Korku ve Üzüntü Duygusunu Aktarmada Kullanilan Terkipler (Fuzûlî, Bâkî, Nâilî, Neşâtî Örneği)

\begin{tabular}{|c|c|c|c|c|}
\hline Üzüntü & Fuzûlî & Bâkî & Nâilî & Neşâtî \\
\hline Hastalık & $\begin{array}{l}\text { illet-i endûh } \\
\text { (G 49/1) }\end{array}$ & & & \\
\hline Kafes & & $\begin{array}{l}\text { kafes-i gam } \\
\text { (G 422/6) }\end{array}$ & & \\
\hline \multirow[t]{11}{*}{ Ok, kılıç } & $\begin{array}{l}\text { tîğ-i cefâ } \\
(\mathrm{G} 222 / 6)\end{array}$ & tîr-i gam (G 526/5) & $\begin{array}{l}\text { berk-i şemşîr-i cefâ } \\
\text { (G 112/3) }\end{array}$ & $\begin{array}{l}\text { tîğ-i kahr } \\
(\mathrm{K} \mathrm{17/II/1)}\end{array}$ \\
\hline & $\begin{array}{l}\text { tîr-i belâ } \\
\text { (G 290/6) }\end{array}$ & $\begin{array}{l}\text { ser-i peykân-1 gam } \\
\text { (G 137/3) }\end{array}$ & $\begin{array}{l}\text { tîğ-i cefâ }(\mathrm{K} \\
21 / 19)\end{array}$ & $\begin{array}{l}\text { tîr-i cefâ } \\
\text { (G 16/3) }\end{array}$ \\
\hline & $\begin{array}{l}\text { hedef-i nâvek-i } \\
\text { belâ } \\
\text { (Msd 2/8) }\end{array}$ & $\begin{array}{l}\text { tîr-i gam-1 nigâr } \\
\text { (G 92/1) }\end{array}$ & tîr-i cefâ (K 13/1) & \\
\hline & $\begin{array}{l}\text { zahm-i hadeng-i } \\
\text { belâ } \\
\text { (K 26/33) }\end{array}$ & tîr-i belâ (G 298/1) & & \\
\hline & & tîr-i belâ (G 262/1) & & \\
\hline & & seyf-i belâ (G 79/5) & & \\
\hline & & $\begin{array}{l}\text { peykân-1 belâ } \\
\text { (G 356/2) }\end{array}$ & & \\
\hline & & $\begin{array}{l}\text { hâdeng-i belâ } \\
\text { (G 477/4) }\end{array}$ & & \\
\hline & & $\begin{array}{l}\text { şemşîr-i dest-i kahr } \\
\text { (G 153/5) }\end{array}$ & & \\
\hline & & tîğ-i cefâ (G 409/5) & & \\
\hline & & $\begin{array}{l}\text { Tî̆g-i cefầ } \\
(\mathrm{G} 486 / 2)\end{array}$ & & \\
\hline \multirow[t]{4}{*}{ Diken } & $\begin{array}{l}\text { def-i hâr-i kahr } \\
\text { (K 24/20) }\end{array}$ & $\begin{array}{l}\text { hırâş-1 hâr-1 gam } \\
\text { (G 202/4) }\end{array}$ & $\begin{array}{l}\text { hâr-1 gam u endûh } \\
\text { (G 383/2) }\end{array}$ & \\
\hline & & $\begin{array}{l}\text { mugaylân-ı belâ } \\
\text { (G 316/5) }\end{array}$ & $\begin{array}{l}\text { hırâş̧-1 hâr-1 cefâ } \\
\text { (K 7/13) }\end{array}$ & \\
\hline & & & $\begin{array}{l}\text { hâr-1 gam u endûh } \\
\text { (G 383/2) }\end{array}$ & \\
\hline & & & hâr-1 gam (G 54/1) & \\
\hline \multirow[t]{4}{*}{ Dağ } & $\begin{array}{l}\text { kûh-1 belâ } \\
\text { (G 186/3) }\end{array}$ & $\begin{array}{l}\text { kulle-i kûh-1 cefâ } \\
\text { (K 23/6) }\end{array}$ & $\begin{array}{l}\text { kûh-1 belâ } \\
\text { (G 180/5) }\end{array}$ & \\
\hline & & $\begin{array}{l}\text { kûhsâr-1 kahr } \\
\text { (K 14/14) }\end{array}$ & & \\
\hline & & $\begin{array}{l}\text { peleng-i kûh-1 gam } \\
\text { (G 133/5) }\end{array}$ & & \\
\hline & & kûh-1 belâ (G 321/2) & & \\
\hline
\end{tabular}




\begin{tabular}{|c|c|c|c|}
\hline Zorlu yol & $\begin{array}{l}\text { mazâyik-i reh-i } \\
\text { kahr } \\
(\mathrm{K} 1 / 58)\end{array}$ & & $\begin{array}{l}\text { şeb-i târik-i belâ } \\
\text { (G 27/4 } \\
\text { şehrâh-1 belâ } \\
\text { (G 172/5) }\end{array}$ \\
\hline \multirow[t]{3}{*}{ Asker } & & $\begin{array}{l}\text { leşger-i endûh } \\
\text { (G 225/5) }\end{array}$ & $\begin{array}{l}\text { cünd-i gam } \\
\text { (K 17/6) }\end{array}$ \\
\hline & & leşger-i gam (G 23/3) & \\
\hline & & $\begin{array}{l}\text { sipâh-1 gam } \\
\text { (G 169/4) }\end{array}$ & \\
\hline
\end{tabular}

Delici alet

miskab-1 endûh

(M I/4)

nâhün-i gam

(G 285/5)

\begin{tabular}{lllll}
\hline Girdap & $\begin{array}{l}\text { sevâd-1 gird- } \\
\text { bâd-1 kahr }\end{array}$ & girdâb-1 belâ & girdâb-1 belâ $(\mathrm{G}$ & girdâb-1 belâ \\
$(\mathrm{Kt} 22 / 2)$ & $(\mathrm{G} \mathrm{510/6)}$ & $58 / 1)$ & $(\mathrm{G} \mathrm{122/2})$ \\
& girdâb-1 belâ & & \\
& $(\mathrm{G} \mathrm{286/4)}$ & & \\
\hline
\end{tabular}

\begin{tabular}{|c|c|c|c|c|}
\hline \multirow{8}{*}{\multicolumn{2}{|c|}{ Ateş }} & $\begin{array}{l}\text { nişân-1 âteş-i endûh-1 } \\
\text { 'aşk-1 yâr (G 335/4) }\end{array}$ & $\begin{array}{l}\text { berk-i belâ } \\
\text { (G 279/4) }\end{array}$ & $\begin{array}{l}\text { dûzah-âşâm-1 } \\
\text { gam } \\
\text { (G 129/1) }\end{array}$ \\
\hline & & $\begin{array}{l}\text { şirâr-i nâr-1 gam (G } \\
265 / 3)\end{array}$ & $\begin{array}{l}\text { tef-i kahr } \\
\text { (K 12/33) }\end{array}$ & $\begin{array}{l}\text { tef-i kahr } \\
\text { (K 9/23) }\end{array}$ \\
\hline & & $\begin{array}{l}\text { şirâr-1 nâr-1 hır- } \\
\text { men-sûz-1 gam (G } \\
\text { 335/4) }\end{array}$ & $\begin{array}{l}\text { hânümân-sûz-1 } \\
\text { belâ } \\
\text { (G 327/1) }\end{array}$ & \\
\hline & & $\begin{array}{l}\text { dûzah-1 cevr ü cefâ } \\
\text { (G 191/5) }\end{array}$ & $\begin{array}{l}\text { cilvegeh-i berk-1 } \\
\text { belâ } \\
\text { (G 113/1) }\end{array}$ & \\
\hline & & nâr-1 kahr (K 5/11) & $\begin{array}{l}\text { âteş-i gam }(G \\
210 / 3)\end{array}$ & \\
\hline & & $\begin{array}{l}\text { nâr-1 mihnet (G } \\
\text { 236/2) }\end{array}$ & âteş-i gam (M II/2) & \\
\hline & & & $\begin{array}{l}\text { âteş-i gam (M } \\
\text { III/5) }\end{array}$ & \\
\hline & & & $\begin{array}{l}\text { külhen-i gam } \\
\text { (G 14/2) }\end{array}$ & \\
\hline \multirow[t]{2}{*}{$\begin{array}{l}\text { Acı, öldü- } \\
\text { rücü tat }\end{array}$} & $\begin{array}{l}\text { zehr-i kahr } \\
\text { (G 127/7) }\end{array}$ & zehr-i gam (K 10/8) & $\begin{array}{l}\text { mest-i zehrâbe-i } \\
\text { cefâ-yı dil (K 4/19) }\end{array}$ & $\begin{array}{l}\text { semûm-1 nâm-1 } \\
\text { kahr (K 10/28) }\end{array}$ \\
\hline & $\begin{array}{l}\text { telh-i kahr } \\
\text { (K 36/22) }\end{array}$ & zehr-i belâ ( $\mathrm{G}$ 544/1) & $\begin{array}{l}\text { zehr-i kahr-1 cefâ } \\
\text { (G 214/1) }\end{array}$ & $\begin{array}{l}\text { semûm-1 kahr } \\
\text { (K 21/31) }\end{array}$ \\
\hline
\end{tabular}




$\begin{array}{lll}\text { teff-i semûm-1 kahr } & \text { zehrâb-1 gam } & \text { nişter-i zehr-i } \\ \text { (M 2 1/5) } & \text { (G 281/5) } & \text { belâ (K 27/34) } \\ & & \text { semûm-1 germ- } \\ & & \text { kahr } \\ & & \text { (K 25/14) }\end{array}$

\begin{tabular}{|c|c|c|c|c|}
\hline $\begin{array}{l}\text { Gül } \\
\text { bahçesi }\end{array}$ & $\begin{array}{l}\text { gülşen-i kahr } \\
\text { (K 10/42) }\end{array}$ & & $\begin{array}{l}\text { gülsitân-1 derd ü } \\
\text { gam } \\
\text { (G 41/1) }\end{array}$ & \\
\hline & & & gülzâr-1 gam (Kt 4) & \\
\hline \multirow[t]{7}{*}{$\begin{array}{l}\text { Okyanus, } \\
\text { deniz, } \\
\text { akarsu }\end{array}$} & & $\begin{array}{l}\text { lücce-i gam } \\
\text { (G 152/6) }\end{array}$ & $\begin{array}{l}\text { hurûş-1 mevc-i belâ } \\
(\mathrm{K} 7 / 21)\end{array}$ & $\begin{array}{l}\text { lücce-i mâtem } \\
\text { (K 5/II/8) }\end{array}$ \\
\hline & & $\begin{array}{l}\text { lücce-i gam } \\
\text { (G 366/3) }\end{array}$ & $\begin{array}{l}\text { mevc-i yem-i belâ } \\
\text { (G 53/3) }\end{array}$ & $\begin{array}{l}\text { lücce-i mihnet } \\
\text { (R 7) }\end{array}$ \\
\hline & & $\begin{array}{l}\text { garîk-i bahr-i gam } \\
\text { (G 531/5) }\end{array}$ & $\begin{array}{l}\text { bahr-1 gam } \\
\text { (G 201/2) }\end{array}$ & $\begin{array}{l}\text { cûy-1 belâ } \\
\text { (K 5/IV/9) }\end{array}$ \\
\hline & & $\begin{array}{l}\text { ka'r-1 yem-i gam } \\
\text { (G 195/3) }\end{array}$ & $\begin{array}{l}\text { mevc-i gam } \\
(\text { Ş } 41 / 6)\end{array}$ & \\
\hline & & $\begin{array}{l}\text { emvâc-1 belâ } \\
(\mathrm{K} 11 / 4)\end{array}$ & & \\
\hline & & bahr-i belâ (G 191/4) & & \\
\hline & & bahr-i belâ (G 134/1) & & \\
\hline \multirow[t]{6}{*}{$\begin{array}{l}\text { Yeşil, çiçek- } \\
\text { li bahçe }\end{array}$} & & $\begin{array}{l}\text { lâle-i sîr-âb-1 } \\
\text { çemenzâr-1 cefâ } \\
\text { (G 248/4) }\end{array}$ & & $\begin{array}{l}\text { çemenzâr-1 gam } \\
\text { (K 5/V/6) }\end{array}$ \\
\hline & & $\begin{array}{l}\text { şâh-1 nihâl-i çemen-i } \\
\text { mihnet (G 332/4) }\end{array}$ & & $\begin{array}{l}\text { gülzâr-1 gam } \\
\text { (G 111/3) }\end{array}$ \\
\hline & & bâğ-1 belâ (G 539/3) & & \\
\hline & & bâğ-1 belâ (K 26/8) & & \\
\hline & & bâğ-1 belâ (G 308/6) & & \\
\hline & & bâğ-1 belâ (G 359/7) & & \\
\hline \multirow[t]{3}{*}{$\begin{array}{l}\text { Geniş alan, } \\
\text { mülk }\end{array}$} & $\begin{array}{l}\text { müsâfir-i reh-i } \\
\text { sahrâ-yı mihnet } \\
\text { ü elem } \\
(\text { Msd 2/1) }\end{array}$ & $\begin{array}{l}\text { meydân-1 gam } \\
\text { (G 413/3) }\end{array}$ & tîh-i belâ (M III/1) & $\begin{array}{l}\text { deşt-i belâ } \\
\text { (G 52/3) }\end{array}$ \\
\hline & $\begin{array}{l}\text { şâh-1 mülk-i } \\
\text { mihnet } \\
\text { (G 195/1) }\end{array}$ & $\begin{array}{l}\text { mülk-i gam } \\
\text { (G 148/5) }\end{array}$ & & \\
\hline & $\begin{array}{l}\text { şâh-1 mülk-i } \\
\text { mihnet } \\
\text { (G 236/6) }\end{array}$ & $\begin{array}{l}\text { husrev-i mülk-i gam } \\
\text { (G 54/1) }\end{array}$ & & \\
\hline
\end{tabular}




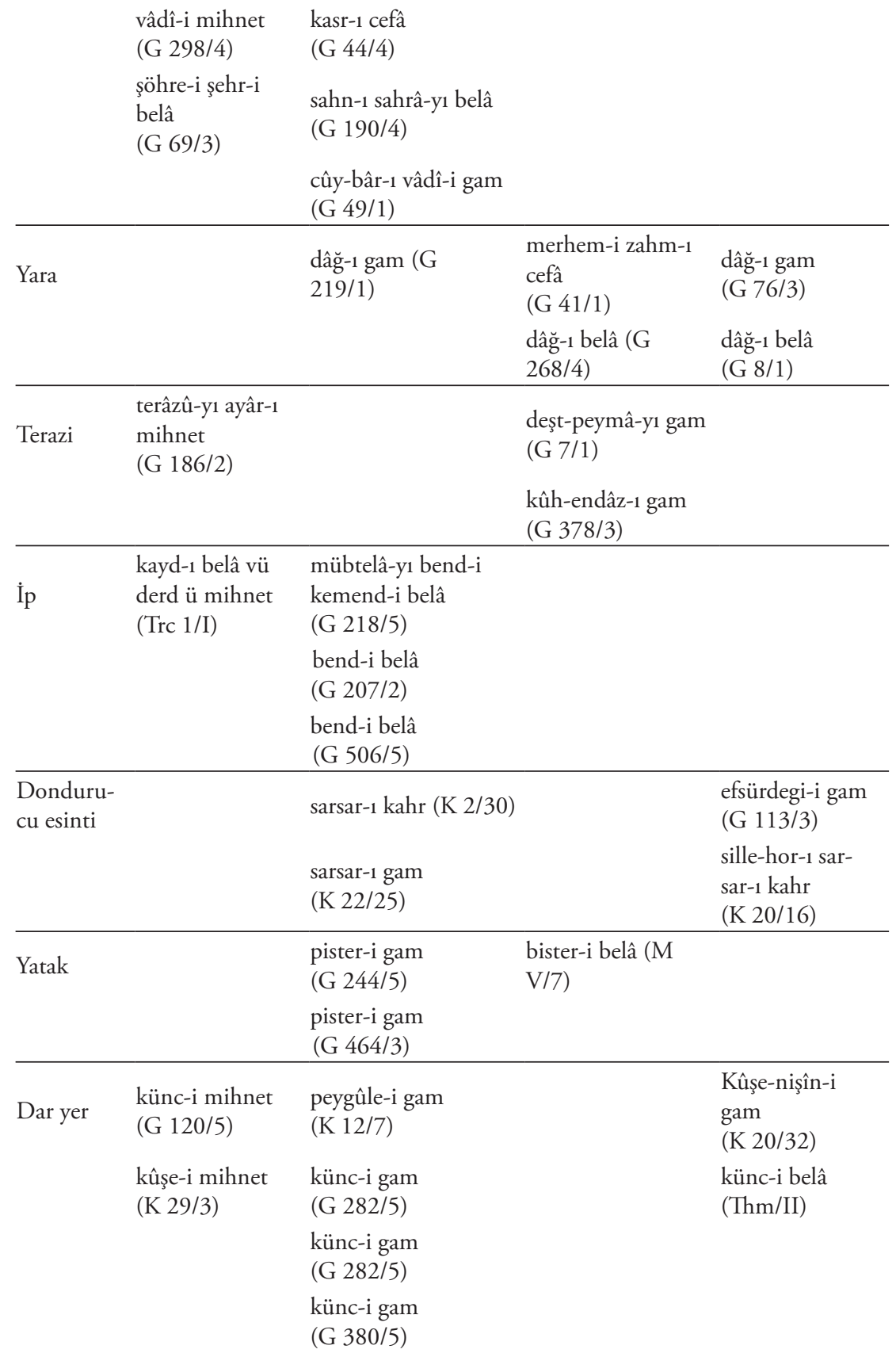




\begin{tabular}{|c|c|c|c|c|}
\hline & & $\begin{array}{l}\text { gûşe-i mihnet } \\
\text { (G 103/7) }\end{array}$ & & \\
\hline & & $\begin{array}{l}\text { künc-i belâ } \\
\text { (G 103/7) }\end{array}$ & & \\
\hline & & $\begin{array}{l}\text { künc-i belâ ( } \\
\text { G 193/2) }\end{array}$ & & \\
\hline Şarap & & $\begin{array}{l}\text { sâgar-1 gam } \\
\text { (G 264/2) }\end{array}$ & $\begin{array}{l}\text { humâr-1 derd-i } \\
\text { keder } \\
\text { (G 14/5) }\end{array}$ & $\begin{array}{l}\text { humâr-1 gam } \\
\text { (K 10/26) }\end{array}$ \\
\hline & & $\begin{array}{l}\text { cürá-i câm-1 belâ-en- } \\
\text { câm-1 gam (K 22/26) }\end{array}$ & $\begin{array}{l}\text { bâde-güsârân-1 gam } \\
\text { (G 60/2) }\end{array}$ & $\begin{array}{l}\text { mahmûr-1 keder } \\
(\mathrm{G} \mathrm{123/2)}\end{array}$ \\
\hline & & $\begin{array}{l}\text { humâr-1 derd ü } \\
\text { mihnet } \\
\text { (K 22/26) }\end{array}$ & $\begin{array}{l}\text { harâbât-1 gam } \\
\text { (G 341/4) }\end{array}$ & $\begin{array}{l}\text { humâr-1 gam } \\
\text { (G 44/4) }\end{array}$ \\
\hline & & & $\begin{array}{l}\text { kadeh-keşân-1 gam } \\
\text { (G 147/1) }\end{array}$ & \\
\hline & & & $\begin{array}{l}\text { sahbâ-yı gam } \\
\text { (G 219/3) }\end{array}$ & \\
\hline Taş & $\begin{array}{l}\text { sengsâr-1 mihnet } \\
\text { (G 91/5) }\end{array}$ & seng-i gam (G 204/2) & & $\begin{array}{l}\text { zahmdâr-1 seng-i } \\
\text { gam } \\
\text { (K 27/35) }\end{array}$ \\
\hline & & $\begin{array}{l}\text { seng-i mihnet }(\mathrm{G} \\
51 / 6)\end{array}$ & & $\begin{array}{l}\text { seng-i cefầ } \\
(\mathrm{G} \mathrm{8/3)}\end{array}$ \\
\hline & & & & $\begin{array}{l}\text { seng-i cefâ } \\
(\mathrm{G} \mathrm{8/3)}\end{array}$ \\
\hline $\begin{array}{l}\text { Başa gelen } \\
\text { büyük } \\
\text { sıkıntı, yük }\end{array}$ & $\begin{array}{l}\text { bâr-1 gam u } \\
\text { mihnet } \\
\text { (G 110/7) }\end{array}$ & bâr-1 belâ $(\mathrm{G} 75 / 3)$ & $\begin{array}{l}\text { tûfân-1 cefâ } \\
\text { (G 138/3) }\end{array}$ & $\begin{array}{l}\text { hâne-ber-endâz-1 } \\
\text { belâ } \\
\text { (G 57/2) }\end{array}$ \\
\hline & $\begin{array}{l}\text { bâr-1 mihnet } \\
\text { (G 214/1) }\end{array}$ & bâr-1 belâ (G 124/5) & $\begin{array}{l}\text { nat'-1 siyâsetgeh-i } \\
\text { kahr (K 9/7) }\end{array}$ & \\
\hline & $\begin{array}{l}\text { bâr-1 mihnet } \\
\text { (G 283/2) }\end{array}$ & $\begin{array}{l}\text { menzil-i bâr-1 belâ } \\
\text { (M 2-1/2) }\end{array}$ & $\begin{array}{l}\text { tâb-1 teb-i kahr } \\
\text { (K 12/35) }\end{array}$ & \\
\hline & $\begin{array}{l}\text { seyl-i tûfan-1 belâ } \\
\text { (G 219/5) }\end{array}$ & & $\begin{array}{l}\text { âfet-i gam } \\
\text { (G 123/1) }\end{array}$ & \\
\hline & & & $\begin{array}{l}\text { bâr-1 gam } \\
\text { (G 324/1) }\end{array}$ & \\
\hline Zindan & $\begin{array}{l}\text { bend ü zindân-1 } \\
\text { gam u mihnet } \\
\text { (G 33/6) }\end{array}$ & $\begin{array}{l}\text { sâkin-i zul- } \\
\text { met-sarây-1 } \\
\text { mihnet } \\
\text { (G 95/2) }\end{array}$ & $\begin{array}{l}\text { zulmet-âbâd-1 gam } \\
\text { (G 354/3) }\end{array}$ & $\begin{array}{l}\text { derûn-1 tîre-i } \\
\text { gam (K 21/29) }\end{array}$ \\
\hline & $\begin{array}{l}\text { zindân-1 belâ } \\
\text { (Mrb 1/1) }\end{array}$ & & & $\begin{array}{l}\text { zulmet-i gam } \\
\text { (K 18/2) }\end{array}$ \\
\hline
\end{tabular}


zindân-1 belâ

(G 259/5) zulmet-i gam

(G 100/3)

zulmet-i gam

(G 134/3)

şâm-1 keder

(G 77/5)

\begin{tabular}{lll} 
Akşam & $\begin{array}{l}\text { şem -i şebistân-1 } \\
\text { belâ }\end{array}$ & şâm-1 gam (G 357/4) \\
$(G$ 196/2) & \\
& şâm-1 gam (G 237/1) \\
& şâm-1 gam (G 515/3 \\
& şâm-1 gam (G 95/2) \\
\hline
\end{tabular}

\begin{tabular}{lll}
\hline Aslan & & $\begin{array}{l}\text { pençe-i kahr } \\
(\mathrm{K} 17 / 46)\end{array}$ \\
\hline Sert darbe & & $\begin{array}{l}\text { sadme-i kahr } \\
(\mathrm{K} 2 / 30)\end{array}$ \\
\hline \multirow{2}{*}{ Tuzak } & dâm-1 belâ & dâm-1 belâ $(\mathrm{K}$ \\
& $(\mathrm{G}$ 146/5) & $13 / 13)$ \\
& esîr-i dâm-1 belâ & dâm-1 belâ \\
& $(\mathrm{K} 7 / 11)$ & $(\mathrm{G} 27 / 3)$ \\
& esîr-i dâm-1 belâ & \\
& (K 7/47) & \\
\hline
\end{tabular}

\begin{tabular}{|c|c|c|c|c|}
\hline Pas & & & $\begin{array}{l}\text { mu'tâd-1 tılâ-kârî-i } \\
\text { jengâr-1 keder } \\
(\mathrm{M} \mathrm{II} / 3)\end{array}$ & \\
\hline \multirow{3}{*}{\multicolumn{2}{|c|}{ Toz }} & $\begin{array}{l}\text { gerd-i keder } \\
\text { (G 226/3) }\end{array}$ & $\begin{array}{l}\text { gerd-i keder } \\
\text { (K 13/9) }\end{array}$ & $\begin{array}{l}\text { gerd-i keder } \\
(\mathrm{G} 49 / 3)\end{array}$ \\
\hline & & $\begin{array}{l}\text { gerd-i küdûret } \\
\text { (G 13/4) }\end{array}$ & $\begin{array}{l}\text { gerd-i keder } \\
\text { (K 21/13) }\end{array}$ & \\
\hline & & & $\begin{array}{l}\text { gubâr-1 gam } \\
\text { (G 110/3) }\end{array}$ & \\
\hline Bulut & & & $\begin{array}{l}\text { sehâb-1 keder } \\
\text { (G 30/3) }\end{array}$ & \\
\hline \multirow[t]{2}{*}{$\begin{array}{l}\text { Hazine, } \\
\text { maden }\end{array}$} & $\begin{array}{l}\text { mahz-1 belâ } \\
\text { (G 128/5) }\end{array}$ & & $\begin{array}{l}\text { kân-1 belâ } \\
\text { (M II/2) }\end{array}$ & \\
\hline & & & $\begin{array}{l}\text { elmâs-1 gam } \\
\text { (G 226/1) }\end{array}$ & \\
\hline Gelin & & & $\begin{array}{l}\text { arûs-1 mâtem } \\
\text { (K 7/42) }\end{array}$ & \\
\hline Katil & & $\begin{array}{l}\text { dârû-yı kattâl-i gam } \\
\text { (G 205/3) }\end{array}$ & & \\
\hline Sopa & & & $\begin{array}{l}\text { çevgân-1 belâ } \\
\text { (G 323/2) }\end{array}$ & \\
\hline
\end{tabular}




\begin{tabular}{|c|c|c|c|c|}
\hline Büyücü & & $\begin{array}{l}\text { def'-i Yecûc-1 gam } \\
\text { (K 26/14) }\end{array}$ & & \\
\hline Sonbahar & & & & $\begin{array}{l}\text { hazân-1 keder } \\
\text { (G 125/4) }\end{array}$ \\
\hline \multirow[t]{2}{*}{ Kuş } & $\begin{array}{l}\text { tâiir-i evc-i belâ } \\
\text { (K 30/18) }\end{array}$ & & & $\begin{array}{l}\text { murg-1 pür-belâ } \\
\text { (G 41/2) }\end{array}$ \\
\hline & & & & $\begin{array}{l}\text { bâl-i murgân-1 } \\
\text { belâ } \\
\text { (G 57/4) }\end{array}$ \\
\hline Çarş̧1 & & & $\begin{array}{l}\text { çârsû-yı gam } \\
\text { (G 316/4) }\end{array}$ & \\
\hline Karınca & & $\begin{array}{l}\text { mur-1 gussa } \\
\text { (G 372/1) }\end{array}$ & & \\
\hline
\end{tabular}

Klasik Türk şiirinde duygular içerisinde en çok üzüntü ve sevgi duygusunun somutlaştırılarak aktarıldığı görülmektedir. Üzüntü somutlaştırılırken özellikle bu duyguyu en iyi ifade edecek olan hastalık, kafes, ok, kılıç, diken, dağ, zorlu yol, asker, delici alet, girdap, ateş, zehir, deniz, okyanus, yara, ip, dondurucu esinti, dar yer, taş, yük, zindan, akşam, aslan, sert darbe, tuzak, pas, toz, bulut, katil, sopa, büyücü, sonbahar, tortu, mahşer, çarşı, karınca gibi somut varlıklar seçilmiştir. Gam, bela, sıkıntı gibi üzüntüye sebep olan durumlar, sevgiliye yakın olmaktan kaynaklandığında ise gül bahçesi, yeşil bahçe, geniş alan, terazi, yatak, şarap, hazine, maden, gelin, kuş gibi olumlu anlama sahip somut varlıklara benzetilerek somutlaştırılmaktadır. Fuzûlî, Bâkî, Nâilî ve Neşâtî̀nin divanlarına bakıldığında, üzüntüyü şiirlerinde en çok somutlaştırarak anlatan şairin Bâkî olduğu görülmektedir.

Klasik Türk şiirinde soyut olan duygunun somut bir şekilde gösterilmesi için de somut varlıkların gösterilenlerinin o duyguya aktarılması yolu tercih edilmiştir. Şairlerin soyut olan duygularını daha çok hangi kelimelerle somutlaştırdığına bakılarak onların hayatı ve karakteri hakkında bilgiler edinilebilir. 


\section{Sonuç}

Klasik Türk şiirindeki terkiplerde somutlaştırma ve duygu aktarımının incelenmesiyle terkiplerin, edebî metinlerin en önemli amaçlarından biri olan soyut olanı dolayısıyla duyguları ifade etme görevini üstlendiği görülmüştür. Klasik Türk şiirinde bu somutlaştırma terkiplerinin kullanılmasının sadece Sebk-i Hindî̀yi benimsemiş şairlere özgü olmadığı, Fuzûlî, Bâkî, Nâilî ve Neşâtînin divanlarından alınan örneklere bakıldığında şairlerin bir anlatım yöntemi olarak bu terkipleri tercih ettiği ve özellikle duygu aktarımında kullandığı tespit edilmiştir.

Bu çalışma sonucunda Fuzûlî, Bâkî, Nâilî ve Neşâtînnin divanlarında en çok üzüntü ve sevgi duygusunun somutlaştırılarak aktarıldığı gözlemlenmiştir. Duyguların somutlaştırılmasında şairlerin kullanmış oldukları kelimeler, şairin o duyguyu nasıl hissettiğini veya hissettirmek istediğini net şekilde yansıtmaktadır. Şairin bir terkip ile soyut kavramı nasıl somutlaştırdığı, şiirde oluşturmak istediği hayal ile doğrudan ilgilidir. Bu sebeple terkiplerdeki somutlaştırmalar, şairinin hayal dünyasını görebilmek bakımından oldukça önemli bilgiler sunmaktadır.

Terkiplerle somutlaştırmada dikkat çeken bir diğer husus ise, özellikle klasik Türk şiirinde tat ile yapılan somutlaştırmalarda şarabın oldukça sık kullanılmasıdır. Şarabın verdiği etkinin, birçok soyut kavramın verdiği etkiye benzer olması, somutlaştırmalarda şarabın çok sık kullanılmasını beraberinde getirmiştir. Bazı duyguların ve soyut kavramların verdiği kendinden geçme ve aklını kullanamama özelliği, ancak içilen ve yenilen bir şeyle mümkün olacağından bu soyut kavramlar anlatılırken şaraptan benzetme noktasında faydalanılmıştır.

Terkipler üzerine yapılan bu inceleme sonucunda günlük dilde tercih edilmeyen, daha çok edebî dilin bir parçası olan terkiplerin ve aynı zamanda birer itibari terkip olan bu yapıların kullanılmasının şairlere sağladığı en önemli olanağın soyut kavramların somutlaştırılması ve duygu aktarımı olduğu tespit edilmiştir. 


\section{Açıklamalar}

1 Çalışmada yer alan her beyit için parantez içerisinde şairin adı daha sonra sırasıyla nazım şeklinin adının kısaltması (K: Kaside, G: Gazel, Kt: Kıt 'a, M: Musammat, Msd: Müseddes, Mrb: Murabba, R: Ruba'i, Ş: Şarkı, Thm: Tahmis, Trc: Tercî'-i bend) ardından nazım şeklinin divandaki sıra numarası ve beyit numarası verilmiştir.

\section{Kaynaklar}

Aksan, Doğan. Şiir Dili ve Türk Şiir Dili. Be-Ta Basım Yayım, 1993.

Belli, Handan. Klasik Türk Şiirinde Terkiplerin Edebî Yönü (Fuzûlî, Bâkî, Nâilî ve Neşâtî Örneği). Doktora Tezi. İnönü Üniversitesi, 2017.

Çörtü, Mustafa Meral. Arapça Cümle Kuruluşu ve Tercüme Tekniği. Marmara Üniversitesi İlâhiyat Fakültesi Yayınları, 2009.

Demirel, Şener. "17. Yüzyıl Sebk-i Hindî Şairlerinden Nâilî ve Fehîm’in Şiirlerinde Soyutlama veya Alışılmamış Bağdaştırmalar.” Eski Türk Edebiyatı Çalışmaları I. Sözde ve Anlamda Farklılaşma: Sebk-i Hindî, ed. Hatice Aynur vd., Turkuaz Yayınları, 2006, ss. 34-89.

Doğan, Orhan. Sağlık Bilimleri Alanında Davranış Bilimleri. Cumhuriyet Üniversitesi Yayınları, 1999.

Hacızade, Naile. Bilişsel Dilbilim Açısından Duyguların Dili. Çizgi Kitabevi Yayınları, 2012.

İbn Sînâ. el-Hatâbe min Kitâbi ş-şifâ. Thk. M. Selim Sâlim, 1954.

Gemuhluoğlu, Zeynep. "Metaforların Kognitif İçeriklerinin Felsefe ve Şiir Dili Açısından İncelenmesi -Fârâbî, İbn Sînâ ve İbn Rüşd Örnekleri-.” M.Ü. İlâhiyat Fakültesi Dergisi, vol. 34, no. 1, 2008, ss. 121-144.

İpekten, Haluk, haz. Nailî Divanı. Akçağ Yayınları, 1990.

İz, Mahir. Tasavvuf Mâhiye, Büyükleri ve Tarikatler. Haz. Ertuğrul Düzdağ. Kitabevi, 2012.

Kaplan, Mahmut, haz. Neşâtî̀ Divanı. Akademi Kitabevi, 1996.

Karahan, Leyla, ve Dilek Ergönenç, haz. Hüseyin Cahit, Türkçe Sarf ve Nahiv. TDK Yayınları, 2000.

Karahan, Leyla, ve Ülkü Gürsoy, haz. Tâhir Kenân, Kavâid-i Lisân-ı Türkî. TDK Yayınları, 2004.

Korkmaz, Zeynep. Gramer Terimleri Sözlüğ̈̈. TDK Yayınları, 1992.

Korkut, Ece. "Şiirde Duygu Değeri ve 'Aşsk." Hacettepe Üniversitesi Eğitim Fakültesi Dergisi, no. 12, 1996, ss. 31-35. 
Küçük, Sabahattin, haz. Bâkî Divanı. TDK Yayınları, 1994.

Metinlerle Tasavvuf Terimleri Sözlü̆̆̈̈ (MTTS). Ed. Zafer Erginli, Kalem Yayınevi, 2006.

Mum, Cafer. Halepli Edîb Dîvânı (İnceleme-Tenkitli Metin-Cinaslar Sözlüğü). Doktora Tezi, Hacettepe Üniversitesi, 2004.

Parlatır, İsmail, haz. Fuzulî Türkçe Divanı. Akçağ Yayınları, 2012.

Pürcevâdî, Nasrullah. Can Esintisi İslam'da Şiir Metafiziği. Çev. Hicabi Kırlangıç, İnsan Yayınları, 1998.

Saraç, M. A Yekta. “Tasavvuf Edebiyatında İçki Kavramına Giriş ve Yunus Emre Örneği." İlmî Araştırmalar: Dil, Edebiyat, Tarih İncelemeleri, no. 10, 2000, ss. $135-154$.

Şahinoğlu, M. Nazif. Farş̧a Grameri Sarf ve Nahiv. Kitabevi, 1997.

Tekin, Arslan. Edebiyatımızda Terimler. Elips Yayınları, 2006.

Türk Dil Kurumu (TDK). Türkçe Sözlük. TDK Yayınları, 2011.

Türkay, Kaya, haz. Halid Ziya Uşaklıgil, Kavâid-i Lisân-ı Türkî (Türkçe Dil Bilgisi). TDK Yayınları, 1999.

Uludağ, Süleyman. Tasavvuf Terimleri Sözlüğü. Kabalcı Yayınevi, 1996.

Yıldırım, Ali. "Nedim'in Şiirlerinde Somutlaştırma." Fırat Üniversitesi Sosyal Bilimler Dergisi, vol. 12, no. 2, 2002, ss. 211-218.

Yıldırım, Ali. "Renk Simgeciliği ve Şeyh Gâlib’in Üç Rengi.” Millî Folklor, no. 72, 2006, ss. 129-140. 


\title{
The Concretization and Conveying of Emotion in the Poetic Compounds of Classical Turkish Poetry*
}

\author{
Handan Belli** \\ Cafer Mum ${ }^{* * *}$
}

\begin{abstract}
Within the literary language, it is referred to analogies in the expression of concrete and abstract. Analogies made in the narrative of the abstract are also concretization at the same time. In poetry, it is seen that the concretizations are made by analogy or by using structures such as compounds. Concretization in classical Turkish poetic forms in poetic compounds is directly related to the imagination that the poet wants to create in his poem, and it is the keystone of the imagination in couplet. This article specifically made classical Turkish poetry with classical compositions encountered in almost every poet in Turkish poetry concretization studies are discussed. In addition to Sebk-i Hindî poets such as Nâilî and Neşâtî, it is also desired to see examples of poetry adopting classical styles such as Fuzûlî and Bâkî, and the situation in different periodic styles of the subject of embodying them. The method of concretization especially has been preferred in the conveying of emotions by poetic compounds and many things have been able to be stated with a few words in these concretizations. Besides these compounds by means concretizations in poetry transmission of emotions done effectively the transfer of abstract emotions. In classical Turkish poetry, while conveying of emotion is made it is seen that the imagination of the poet reflects to the poetry, in the poetic compounds in which artistic language usage is realized.

Keywords

Classical Turkish poetry, poetic compound, abstract, concretization, conveying of emotion.
\end{abstract}

\footnotetext{
This article was produced from Handan Belli's doctoral thesis titled Literary Aspect of the Compositions in Classical Turkish Poetry (Fuzûlî̀, Bâkî̀, Nâilî and Neşâtî Example).

Date of Arrival: 06 May 2017 - Date of Acceptance: 19 September 2017

You can refer to this article as follows:

Belli, Handan, ve Cafer Mum. "Klasik Türk Şiirinde Terkiplerdeki Somutlaştırma ve Duygu Aktarımı." bilig, no. 97, 2021, ss. 79-108.

** Ass. Prof., Inonu University, Faculty of Science and Literature, Department of Turkish Language and Literature - Malatya / Turkey ORCID ID: 0000-0002-7732-7912

handan.belli@inonu.edu.tr

${ }^{* * *}$ Prof. Dr. Inonu University, Faculty of Science and Letters, Department of Turkish Language and Literature - Malatya / Turkey

ORCID ID: 0000-0003-0042-5159

cafer.mum@inonu.edu.tr
} 


\title{
Конкретизация и передача эмоций в классической турецкой поэзии
}

\author{
Хандан Белли \\ Джафер Мум ${ }^{* * *}$
}

\begin{abstract}
Аннотация
Литературный язык обращается к способу аналогий для выражения конкретного и абстрактного. Аналогии, проводимые в повествовании об отвлеченном, в то же время представляют собой конкретизацию излагаемого. Было замечено, что конкретизация в поэзии формируется по аналогии и в основном с использованием таких структур, как составные / фразы. В произведениях классической турецкой поэзии конкретизация напрямую связана с образом, который поэт создает в двустишии, и является краеугольным камнем стихотворения. В этом исследовании рассматриваются приемы конкретизации в композициях, встречающихся почти у каждого поэта в классической турецкой поэзии. В дополнение к поэтам литературного направления Sebk-i Hindi, таким как Наили и Нишати, были рассмотрены поэты, которые переняли классический стиль, такие как Физули и Бакы, чтобы показать конкретизацию и эмоциональную передачу у поэтов с разными стилями. Помимо конкретизации посредством композиций, эффектно осуществляется передача отвлеченных, абстрактных понятий. В классической турецкой поэзии при передаче эмоций видно, что воображение поэта отражается в поэзии в поэтических композициях, в которых реализуется использование художественного языка.
\end{abstract}

Ключевые слова

Классическая турецкая поэзия, поэтическая композиция, абстрактность, конкретизация, передача эмоций.

* Данная статья подготовлена на основе докторской диссертации Хандан Белли на тему «Литературный аспект композиций в турецкой классической поэзии (на примере Физули, Бакы, Наили и Нишати)».

Поступило в редакцию: 06 мая 2017 г. - Принято в номер: 19 сентября 2017 г.

Ссылка на статью:

Belli, Handan, ve Cafer Mum. "Klasik Türk Şiirinde Terkiplerdeki Somutlaştırma ve Duygu Aktarımı.” bilig, no. 97, 2021, ss. 79-108.

*** Доц., д-р, Университет Инёню, Факультет естественных наук и литературы, кафедра турецкого языка и литературы - Малатья / Турция

ORCID ID: 0000-0002-7732-7912

handan.belli@inonu.edu.tr

**** Проф., д-р, Университет Инёню, Факультет естественных наук и литературы, кафедра турецкого языка и литературы - Малатья / Турция

ORCID ID: 0000-0003-0042-5159

cafer.mum@inonu.edu.tr 